\title{
ARTIKELEN
}

\section{Grondslagen en methoden van juridisch onderwijs}

\author{
René Foqué
}

\section{Inleiding}

Vertrekpunt van deze bijdrage is de stelling dat het westerse recht is geworteld in een theoretische traditie die in de opleiding als een permanente basis aanwezig moet zijn. Die traditie is tweeërlei. Enerzijds is er de conceptie van theorie als aanschouwen, waarnemen en vertellen van het waargenomene (teruggaand op de Oud-Griekse prefilosofische traditie). In de tweede plaats is er de typisch moderne theorieopvatting die gericht is op conceptualiseren en logisch systematiseren. De doelstelling is dan het bereiken van objectiviteit en (rechts)zekerheid. Betoogd zal worden dat een evenwichtige juridische opleiding haar vertrekpunt én haar leerdoelen vanuit beide opvattingen van theorievorming tot ontwikkeling zal moeten brengen. Het zal daarom noodzakelijk zijn om - meer dan thans het geval is - een samenhangend en in elke discipline erkenbaar methodologisch perspectief in te bouwen. Methodologie mag dan niet worden gereduceerd tot praktische vaardigheden. Het sluitstuk van een dergelijke opleiding zal bestaan uit eigen onderzoek van de student in de vorm van een masterscriptie. Dat alles zal toelaten om een aantal methodologische dilemma's op te lossen in een dialectische samenhang die niet leidt tot wederzijdse uitsluiting van benaderingen, maar veeleer tot complementariteit en wederzijdse verfijning. Zo zullen worden besproken de dilemma's tussen anascopie en katascopie, tussen deductief en inductief redeneren, tussen probleemdenken en systeemdenken, tussen casebased/case-oriented denken en dogmatisch/leerstellig denken. Vanuit de genoemde dilemma's dient in de juridische vorming een door reflectie gewonnen evenwicht te worden opgespoord in de klassieke driehoek die wordt gevormd door rechtszekerheid, rechtvaardigheid en doelmatigheid. Het is precies het zorgvuldig zoeken naar een dergelijk evenwicht dat past bij Aristoteles' pleidooi voor phronèsis, of prudentie. Om dit te kunnen realiseren verdient het sterke aanbeveling om in het onderwijs het Europees recht te hanteren als een laboratorium voor rechtsvorming en rechtsontwikkeling. Immers: in de opleiding dient het recht op expliciete wijze gecontextualiseerd te blijven in de geschiedenis - diachronisch via de rechtsgeschiedenis, en synchronisch via de (Europese) rechtsvergelijking. 


\section{De vorming van professionals}

De westerse rechtsontwikkeling is altijd nauw verbonden geweest met de wijze waarop de juridische professionals werden gevormd. Wetenschap en rechtspraktijk zijn daarin sterk met elkaar verweven.

In de eerste plaats speelt de sterke verwetenschappelijking van het recht sinds de studie van het Romeinse recht in de elfde/twaalfde eeuw aan de universiteit van Bologna een beslissende rol. Maar ook het conflictoplossend vermogen van de rechtspraktijk in een zich ook toen al transformerende en pluralistische samenleving is een beslissende factor. In zijn breed opgezette studie Law and Revolution stelt de Harvard-rechtshistoricus Harold J. Berman dat er voor de analyse en de verklaring van juridische leerstukken en instituties overigens geen onderscheid valt te maken tussen enerzijds de westerse traditie zoals die uit de school van Bologna is voortgekomen en anderzijds de typische kenmerken van het moderne recht: westers en modern vallen hier goeddeels met elkaar samen. Het didactisch programma van Bologna betekent tegelijk de start van de juridische moderniteit. ${ }^{1}$

Berman merkt op dat vanaf het begin van het academisch juridisch onderwijs in de elfde eeuw een sterk onderscheid wordt gemaakt tussen juridische instituties en gedragsnormen enerzijds, en gewoonten, die vaak zijn gebaseerd op religie, moraliteit of politiek anderzijds. Natuurlijk wordt de invloed van de laatste soort normen op de eerste soort niet ontkend, maar in de studie en het onderwijs van het recht worden zij analytisch scherp van elkaar onderscheiden.

Dat hangt, aldus Berman, samen met een tweede opvallende vaststelling. De rechtsontwikkeling wordt vanaf de stichting van de eerste juridische faculteiten in Europa toevertrouwd aan een specifieke groep van professionals, aan juridische vakspecialisten. Dat is in een dubbel opzicht het geval. In de eerste plaats gaat het om professionals in de praktische toepassing van juridische instituties en leerstukken. In de tweede plaats zijn deze professionals ook getraind in het logisch correct conceptualiseren en systematiseren van hun vaak pragmatisch opgedane kennis. Juridische professionaliteit betreft zowel de praktische als de theoretische componenten van de rechtsontwikkeling. Sterker nog: een behoorlijke rechtsontwikkeling dient een sterk evenwicht in te houden tussen pragmatiek en theoretische reflectie. Beide polen worden geacht de twee kanten te zijn van één en dezelfde medaille. Daardoor kan en dient het recht te ontsnappen aan de grillige willekeur van de casuïstiek en toegang te verschaffen tot een meer algemeen geldend perspectief van maatschappelijke normering. Berman concludeert: 'The law contains within itself a legal science, a meta-law, by which it can be both analyzed and evaluated' (Berman 1983, p. 7-8).

De vorming van juridische professionals, die in even sterke mate worden voorbereid voor de praktijk als voor de theorie van het recht, en die zijn geoefend in hel-

1 Het didactisch programma van de Bolognese school dreef sterk op de methodologische kurk van het scholastieke denken. Zie hierover: Foqué 1997. 
der conceptualiseren en systematiseren van kennis als onmisbaar kritisch perspectief en toetssteen voor de praktijk van geschillenbeslechting, vormt dé uitdaging voor elke juridische opleiding.

Het is daarbij van het grootste belang dat de aankomende jurist van bij de aanvang van de studie doordrongen is van het inzicht dat rechten studeren niet in de eerste plaats het uit het hoofd leren van rechtsregels inhoudt, maar dat het veel dieper gaat om het leren van een nieuwe taal van onderling samenhangende concepten als bijvoorbeeld rechtssubject, rechtshandeling, rechtsfeit, subjectief en objectief recht, enzovoort. En vooral, dat die specifieke taal - zo leert ons de Bolognese school - geworteld is in een specifieke theoretische traditie, die op haar beurt samenhangt met maatschappelijke en culturele ontwikkelingen. Zo beschouwd heeft zowel de rechtsgeschiedenis als de rechtsvergelijking een belangrijke bijdrage te leveren aan de juridische vorming.

De rechtsgeschiedenis geeft immers inzicht in het diachrone perspectief van de rechtsontwikkeling en in de wijze waarop in de geschiedenis het recht weet om te gaan met de grote normatieve vraagstukken die zich in de samenleving stellen. De rechtsvergelijking opent, complementair hieraan, een synchrone toegang tot de wijze waarop het recht weet om te gaan met culturele en maatschappelijke diversiteit zonder zijn conceptuele consistentie in gevaar te brengen en zonder te verkruimelen in onderling sterk tegenstrijdige en elkaar ondergravende ontwikkelingen.

Berman opnieuw: 'It is presupposed in the Western legal tradition that changes do not occur at random but proceed by reinterpretation of the past to meet present and future needs. The law is not merely ongoing; it has a history. It tells a story.' (Berman 1983, p. 9) In de juridische opleiding zal er zorg voor moeten worden gedragen dat het verhaal dat in het recht impliciet wordt verteld, steeds opnieuw aan de oppervlakte wordt gebracht en wordt gereconstrueerd en geactualiseerd. Dat is de enige weg om de rechtsontwikkeling zowel in haar dieptelagen als in haar directe verschijningsvorm inzichtelijk te maken. De toekomstige jurist dient rechtsvormend, veeleer dan rechtstoepassend te leren denken. Rechtsvormend betekent hier dat de toekomstige jurist in staat moet zijn om de te gelden normen zélf te construeren vanuit de grondbeginselen van onze rechtsorde, en vanuit een goed begrip van de steeds wisselende maatschappelijke context waarin de norm te gelden heeft. Rechtsvormend kunnen denken is een absolute noodzakelijkheid voor de jurist wiens kennis van het regelsysteem dat hij tijdens zijn studie heeft geleerd enkele jaren na afstuderen al verouderd dreigt te zijn. De voormalige Rotterdamse hoogleraar Ter Heide duidde dit treffend aan met het vermogen van de jurist om 'het actuele ordenings- en waarderingsplan' achter de regel te kunnen confronteren met 'het historische ordenings- en waarderingsplan' dat vroeger aan de wetgeving ten grondslag was gelegd (Ter Heide 1967, p. 24-25). Om dat vermogen te ontwikkelen, zal de toekomstige jurist niet alleen moeten worden gevormd in de systematiciteit en in de beginselen die het rechtssysteem kenmerken, maar ook in de ethiek, de politieke filosofie en de sociale wetenschappen. 
Daarbij is het inzicht van belang dat het vermogen van een rechtsorde om zich over de eeuwen heen niet alleen te verfijnen maar ook te veranderen alleen mogelijk is doordat de westerse rechtsorde een ingebouwd veranderingsmechanisme in zich draagt, dat wordt gevormd door een samenhangend systeem van begrippen en procedures, kortom: door theorievorming (Berman 1983, p. 9).

\section{De juridische vorming is geworteld in een dubbele theoretische traditie}

Wanneer zo-even werd gesteld dat de taal van het recht sinds Bologna geworteld is in een specifieke theoretische traditie, dan vraagt dat tegen deze achtergrond om enige verduidelijking van de rijke en veelzijdige betekenis van het begrip theorie. Die veelzijdigheid dient zorgvuldig te worden doorgetrokken in alle fasen van de juridische opleiding. Zij kan op het spoor worden gekomen vanuit het onderscheid tussen enerzijds een eerder sacrale prefilosofische opvatting van theoria zoals die in de Oud-Griekse traditie werd gearticuleerd (Rausch 1982, p. 9-47), en anderzijds een meer filosofische opvatting zoals die zich heeft ontwikkeld na Aristoteles naar de moderne filosofie toe met het uiteindelijk daarin aanwezige ideaal van het more geometrico wetenschappelijk denken bij auteurs als Leibniz, Hobbes en Descartes. ${ }^{2}$

In de juridische opleiding zijn beide theorieopvattingen van belang. De eerste kan de toekomstige jurist vertrouwd maken met de wijze waarop de rechtsorde een antwoord tracht te vinden op de grote normatieve kwesties van samenleving en cultuur. Dat laatste is precies wat Berman bedoelde met de gedachte dat 'the law tells a story'. De tweede theorieopvatting, de meer conceptuele invulling van theorie, is van belang om de toekomstige jurist vertrouwd te maken met de logischconsistente en dus zekerheid scheppende wijze waarop het recht zijn functie vervult. Beide opvattingen kunnen, zo bezien, niet los van elkaar worden beoefend.

In haar Oud-Griekse, prefilosofische betekenis betekent theoria in de eerste plaats aanschouwen, kijken, deelnemen en vervolgens terugvertellen wat men heeft gezien. Aanvankelijk waren de theoroi, de theoretici, de feestgezanten die werden uitgezonden naar andere steden om daar hun gemeenschap te vertegenwoordigen en er deel te nemen aan de gemeenschappelijke cultus, aan vieringen waarin de goede nabuurschap, vrede en vriendschap werden gevierd. In de participatie aan dergelijke feestelijkheden werden de narratieve vormen, de verhalen en de theatrale voorstellingen zichtbaar waarin een politieke gemeenschap zich weet te constitueren en te bestendigen. ${ }^{3}$ Vervolgens keerden de theoroi weer huiswaarts om te vertellen wat zij hadden gezien en meegemaakt, om samen met de hunnen voor de eigen gemeenschap daaruit lering te kunnen trekken. Gaandeweg werd het

2 Ik maak hier gebruik van mijn in eerdere publicaties reeds geformuleerde gedachten (Foqué 2001).

3 De benaming theoroi werd ook gebruikt om er diegenen mee aan te duiden, die naar het orakel werden uitgezonden om er de wil van de goden te vernemen. In beide betekenissen heeft de term aanvankelijk een sacrale, goddelijke betekenis. De meer profane connotaties zullen echter, ook in de prefilosofische opvatting van theorie, een steeds dominantere rol gaan spelen. 
betekenisbereik van termen als theoria en theoroi verruimd tot diegenen die naar het theater trokken om er te aanschouwen wat er werd vertoond: wat er onherroepelijk staat te gebeuren wanneer men verstrikt geraakt in een spiraal van geweld, van doodslag en wraak of wat het lot is van diegene die zich - hoe edel ook - onttrekt aan de wetten van de kosmos.

De ervaringen van de theoroi in de microkosmos van het theater leverden hun het onontkoombare inzicht dat de menselijke bestaanswijze wordt bepaald door het feit dat wij allen in Geschichten verstrickt zijn en dat wij slechts tot inzicht in onszelf en in de samenleving met anderen kunnen komen door in en bij dat complexe netwerk van geschiedenissen betrokken te geraken. ${ }^{4}$ Aan dat inzicht kan en mag de juridische professionaliteit niet voorbijgaan. Doet zij dat wel, dan zal zij zich totaal vervreemden van de samenleving waarin het recht te gelden heeft.

Dat belangrijke inzicht kan echter alleen tot wasdom komen wanneer de betrokkenheid van de juridische professional bij het directe verhaal van de maatschappelijke feitelijkheid tegelijk in evenwicht wordt gehouden door distantie. De ware theoroi zijn diegenen die weer afstand nemen, die weggaan en terugkeren naar hun oorspronkelijke gemeenschap om er verslag te doen van waar zij kijkend en luisterend bij betrokken zijn geraakt. In hun reisverslag kunnen de ervaringsgerichte contouren zichtbaar worden van de wijzen waarop individuele levensgeschiedenissen een toegang zouden kunnen vinden tot een omvattender proces van gemeenschapsvorming, van politiek en recht, om uiteindelijk te kunnen uitmonden in een perspectief van evenwicht en harmonie.

Het betekenisveld dat verbonden was met de prefilosofische opvatting van theoria wordt in Aristoteles' visie nader uitgewerkt in wat hij - in onderscheid tot het zuivere theoretische weten - het praktische weten noemt: de phronèsis - verstandigheid (Steel 1989) - die, anders dan de sophia - geleerdheid van het zuiver theoretische weten, gericht is op zorgvuldige en passende oordeelsvorming of beslissing (Fink 1976). Praktisch kennen heeft altijd te maken met het concrete en het individuele, met het domein van het menselijke handelen, dat in vrijheid tot stand komt. Het wordt gekenmerkt door het toevallige, het onverwachte en onvoorspelbare. Zekere kennis, zoals die mogelijk is in de natuurwetenschappen en in de metafysica, is dan niet mogelijk. Praktisch weten betreft het mogelijke en het wenselijke in plaats van het zekere of het objectieve. In die zin is het steeds gericht op een toekomst die nog niet vaststaat. ${ }^{5}$ Wie meent wetenschappelijke zekerheid te kunnen bereiken in het praktische kennen, ontkent de menselijke

4 De uitdrukking komt van Husserls leerling Wilhelm Schapp, In Geschichten verstrickt. Zum Sein von Mensch und Ding (1953). Schapp was, naast (fenomenologisch) filosoof, ook praktijkjurist.

5 De fenomenoloog Eugen Fink, net als Wilhelm Schapp een leerling van Husserl, formuleert het in zijn bespreking van Aristoteles' phronèsis-begrip als volgt: 'Die praktische Wahrheit steht im Bezug zur noch nicht festgelegten Zukunft, die als Spielraum der menschlichen Freiheit - und nicht als das durch Naturgesetze schon geregelte Feld künftiger Folgen gegenwärtiger Ursachen anzusehen ist. Also nicht auf die nur unbekannte Zukunft, sondern auf die noch nicht festgelegte, noch freie Zukunft hin geschieht das menschliche Handeln; es versteht sich selbst als ein solches, das erst das Künftige entscheidet und so oder so verwirklicht' (Fink 1976, p. 136-137). 
vrijheid en gaat voorbij aan de innoverende kracht van het handelen. Zijn theorievorming dreigt daardoor totalitaire trekken te krijgen. ${ }^{6}$

\section{Zorgvuldigheid door theoretische vorming: een aristotelische gedachte}

In de zorgvuldigheid en doordachtheid van het praktische weten klinken de hoofdlijnen door van het prefilosofische theoria: de betrokkenheid bij en het empathisch vermogen om door te kunnen dringen in het singuliere detail van de individuele levensgeschiedenis van mensen, niet uit ongezonde nieuwsgierigheid, maar integendeel gericht op het vermogen om die individuele ervaringswereld te kunnen plaatsen in het transcenderende perspectief van de samenhang der dingen. Dat is de wijze waarop het phronetische weten zicht kan krijgen op datgene wat waardevol is en bescherming verdient. Zo begrepen bevindt de aristotelische phronèsis zich in het hart van de rechtsgeleerdheid. In het Latijn betekent phronèsis: prudentia. De verstandigheid en bezonnen zorgvuldigheid van en door het recht: iuris prudentia.

Phronèsis en theoria: in het vertonen en in het aanschouwen van de concrete - men zou kunnen zeggen: in de casuïstische - ervaring van de dramatis personae is tegelijk de reflectie aan de orde op de algemenere betekenis en op de algemenere normatieve dimensie van die casuïstiek. De tragedies fungeren als leading cases van de Griekse cultuur.

In het moderne cultuurbeeld is deze oorspronkelijke betekenis van theorie al te zeer op de achtergrond geraakt. Onder theorie verstaan we thans vaak - ten onrechte en in afwijking van het eerder prefilosofische theoriebegrip - veeleer het naar binnen gekeerde denken dat zich verre zou moeten houden van het gewoel van de dagelijkse ervaring om niet gestoord en misleid te worden door de list van onze zintuigen. Theorieën worden dan vooral beoordeeld naar interne criteria van logiciteit, van systematische begripsvorming en van de zuiverheid van conceptuele constructies. Die haast exclusieve aandacht voor de interne, constructivistische merites van theorievorming eist evenwel een hoge, ja een te hoge prijs: het recht wordt contextloos gemaakt en de rechtsbeoefening verliest gaandeweg haar reflexief vermogen in de confrontatie met de maatschappelijke werkelijkheid waarin het recht niettemin te gelden heeft. ${ }^{7}$

De jonge Rudolph von Ihering, nog geheel in de ban van de Historische Rechtsschule waarschuwde de negentiende-eeuwse Duitse professional nog in niet mis te verstane woorden dat hij zich niet door de grillige alledaagse feiten in verlegenheid mocht laten brengen. Deze waarschuwing is in de huidige continentale

6 Zie in aristotelische zin: Arendt 1958, p. 188 e.v..

7 Dit was bij uitstek het geval in het negentiende-eeuwse legalistische denken van de Franse École de l'exégèse en van de Duitse Begriffsjurisprudenz, die door Eggens in zijn Amsterdamse oratie uit 1958 nog treffend en tegelijk smalend werd aangeduid als Unbegriffsjurisimprudenz (Eggens 1958, p. 318). 
rechtsvorming vaak nog actueler dan men beseft of expliciet wil toegeven. Voor Von Ihering was dit alles inzet van een expliciete polemiek:

'Denn in wie ungewöhnlichen, abweichenden Bildungen sich auch der fortschreitende Verkehr ergeben möge, die Besorgnis, dass er uns etwas absolut Neues bringen könnte, d.h. etwas, was nicht unter irgend einen unserer bisherigen Begriffe fiele, und wäre derselbe auch noch so allgemein, - diese Besorgnis ist eben so unbegründet, als wenn man glauben wollte, es könnten heutzutage noch Thiere entdeckt werden, die im zoologischen System der heutigen Wissenschaft absolut kein Unterkommen fanden. Eine Jurisprudenz die seit Jahrtausenden arbeitet, hat die Grundformen oder Grundtypen der Rechtswelt entdeckt, und in ihnen hält sich auch alle fernere Bewegung, so sehr sie im Uebrigen von der bisherigen divergieren möge; eine solche Jurisprudenz läßt sich nicht mehr durch die Geschichte in Verlegenheit setzen.'8

Het zal duidelijk zijn dat de Besorgnis waarover Von Ihering hier spreekt, nog weinig te maken heeft met de zorgvuldige bezorgdheid van de aristotelische phronèsis.

\section{De professional self-consciousness van de toekomstige jurist}

In dat perspectief geplaatst is een terugkeer naar de prefilosofische en naar de aristotelische traditie, en bovenal naar de complementariteit tussen beide tradities geen overbodige luxe als we worden geconfronteerd met de gelding van het recht in een veranderende en pluriforme samenleving. Immers: juist dán vereist de beoefening van het recht een helder professioneel zelfbewustzijn en een uiterste concentratie op wat er gebeurt in alle stappen van de rechtsbedeling (Ter Heide 1967, p. 4). De Duitse rechtsgeleerde Karl Larenz heeft de voor een behoorlijke rechtsbedeling noodzakelijke theoretische dimensie treffend omschreven als 'Reflexion auf eigenes Tun' (Larenz 1960). Die karakterisering past in de Aristotelische traditie. Hij die ooit eens eenmalig geproefd heeft van theorievorming - bijvoorbeeld in zijn academische basisopleiding - maar verder op de eenmaal verworven kennis verder blijft dobberen, zonder zich steeds weer vragen te stellen of zich te laten verontrusten door de vaak verrassende ervaringswerelden van mensen, kan nooit in staat zijn tot bezonnen en verstandig optreden. Hij zal niet prudent handelen. Het leven van een professioneel zelfbewust jurist dient te worden gedragen door een sterk ontwikkeld reflexief vermogen. De Reflexion auf eigenes Tun dient een levensvorm te zijn die wordt volgehouden als toekomstgerichte inspiratiebron van het handelen, het oordelen en beslissen.

De excursie naar het Oud-Griekse denken over de betekenis van theoriebeoefening brengt ons op een genuanceerde wijze terug naar de professional self-consciousness van de huidige jurist, die slechts ten volle tot wasdom zal kunnen komen in 
de eenheid van theorie en praxis, van conceptueel denken en narratieve gevoeligheid voor de feiten van mens en samenleving.

Abstracte begrippen en leerstukken kunnen nooit in de plaats treden van de feiten, noch van de levende pragmatiek van de rechtsbeoefening die dan gereduceerd zou worden tot het mechanisch toepassen van voorop vastgelegde en versteende conceptuele schema's, zoals dat in het negentiende-eeuwse legisme het geval was. Nochtans is zulks tot op de dag van vandaag een aantrekkelijke en verleidelijke reductie voor een bureaucratisch gestuurd juridisch massaonderwijs, met teruglopende middelen en een langzamerhand dramatisch onevenwicht in de student/docent-ratio aan onze juridische faculteiten. ${ }^{9}$ Dat laatste verklaart ook wellicht waarom er in de juridische faculteiten over heel Europa uiteindelijk bitter weinig is veranderd sinds de negentiende eeuw, ondanks de uitvoerige rechtstheoretische literatuur over rechtsvinding in de tweede helft van de vorige eeuw. Ironisch merkt de Duitse rechtsgeleerde Rudolph Wassermann op: 'Es gibt eine Geschichte der Reform der Juristenausbildung, aber der Reform findet nicht statt' (Wassermann 1979, p. 8).

Het wordt dringend tijd dat - ook in een situatie van schaalvergroting en van massaonderwijs - de consequenties worden geconcretiseerd van het onontkoombare inzicht dat een rechtsorde zich steeds afspeelt op twee niveaus tegelijk die - zoals eerder werd opgemerkt - nauw met elkaar samenhangen en op elkaar inwerken: het niveau van de feitelijke pragmatiek en casuïstiek enerzijds en anderzijds het metaniveau van de beginselmatige en conceptuele schema's (Berman) die kritische reflexiviteit en evaluatie van die praktijk toelaten. Die reflexiviteit dient in het onderwijs te worden aangeleerd en in een specifiek programma van academische vaardigheden binnen de onderscheiden juridische disciplines te worden ingeoefend. Om met de woorden van de filosoof Plessner te spreken: het metaniveau van de theorievorming reikt de jurist een excentrische positie aan die hem in staat stelt om uit het vanzelfsprekende centrum van zijn vaak occasioneel doen en laten te treden, zich even te bevrijden uit de tirannie van de casuïstiek, en ruimte te scheppen voor een Reflexion auf eigenes Tun (Plessner 1948). ${ }^{10}$ De juridische professional ontleent zijn gezag dan mede aan het feit dat hij een 'reflective practitioner' wordt die zijn handelen en beslissen weet te kaderen in zorgvuldigheid en in een op waarden georiënteerde visie op de lange termijn (Schön 1983). Jurisprudence is in de common law-traditie niet helemaal toevallig de term voor rechtsleer, veeleer dan voor rechtspraak: iuris prudentia, de zorgvuldigheid die het recht betaamt (Foqué 2004).

9 Zie in die zin, wat Frankrijk betreft, maar met een verderstrekkende continentale relevantie: Gatti-Montain 1987.

10 Met betrekking tot de rechtswetenschap zie Foqué 1995. Larenz pleit voor het ontwikkelen van een methodologie als 'hermeneutische Selbstreflexion der Jurisprudenz'. Het gaat daarbij niet om een psychologische analyse van het besluitvormingsproces, maar om kritische analyse van de gehanteerde methoden en denkvormen (Larenz 1960, p. 246). 


\section{Methodologisch dilemma: anascopie en katascopie}

In zijn Arbeiten zur Soziologie maakt de rechtssocioloog Theodor Geiger een aantal indringende analyses van het methodologieprobleem in de sociale wetenschappen. Wat hij opmerkt over de sociologie geldt in even sterke mate voor de rechtswetenschap. Geiger spreekt van het Doppelaspekt van de sociologische blik op de maatschappelijke werkelijkheid die tegelijk anascopisch én katascopisch hoort te zijn (Geiger 1962, p. 147 e.v.). ${ }^{11}$ Daarin ligt het dubbele karakter van de te hanteren methodologie, zowel in onderwijs als in onderzoek.

Katascopisch noemt Geiger een wijze van denken die hij typeert als een denken dat zich vormt van boven naar beneden. Een dergelijke methode van denken is gaandeweg de hedendaagse sociologiebeoefening gaan domineren, aldus Geiger. Hetzelfde kan worden gezegd met betrekking tot het Europees-continentale rechtsdenken. Dat geldt zeker voor de dominante didactiek die aan de meeste van onze rechtsfaculteiten wordt gehanteerd. Vertrekpunt van een katascopische benaderingswijze zijn de instituties, waarin de individuele personen en hun lotgevallen vervolgens verschijnen als anonieme en abstracte elementen die de werking van die instituties bevestigen, representeren en toepassen. Zo is bijvoorbeeld in de sociologie van Emile Durkheim een dergelijke katascopische benaderingswijze uitgegroeid tot de dominante methode van denken:

'Niet de mens en het menselijk handelen, maar de sociale institutaire struktuur, de instituten als handelingsvormen beschouwde [Durkheim] als het specifieke object van theorie en onderzoek. Volgens deze methode dient de (...) theorie zich te concentreren op een analyse van de overkoepelende structuur der instituten en hun functies.' (Zijderveld 1974, p. 14)

Instituties dienen te worden opgevat als stabiele handelingspatronen waarin het individuele handelen van mensen kan worden geobjectiveerd. Dat betekent dat er van instituties ook een normatieve druk uitgaat, die aan het individu aangeeft hoe hij als lid van de samenleving behoort te handelen.

Institutionalisering van het handelen is een proces dat in het recht nog een extra dimensie verkrijgt. Durkheim, die zelf een juridische opleiding had genoten, kende aan het recht daarom juist een cruciale rol toe in de moderne samenleving. Instituties zijn dragers van waarden, zo meende hij, maar die waarden zijn er altijd impliciet in aan het werk. Zij vormen een geheel, 'qui ne se prête pas à l'observation exacte ni surtout à la mesure'. Om dat laatste mogelijk te maken is de omweg via juridische instituties nodig : 'il faut donc substituer au fait interne qui nous échappe un fait extérieur qui le symbolise et étudier le premier à travers le second. Ce symbole visible, c'est le droit' (Durkheim 1973, p. 28). ${ }^{12}$

11 Ik dank de kennismaking met Theodor Geigers inzichten aan A.C. Zijderveld (o.a. Zijderveld 1974, p. 11-27).

12 Voor een bespreking van de rechtstheoretische consequenties van het debat rond Durkheims sociologische methode, zie Foqué \&'t Hart 1990, p. 233-240. 


\section{Opnieuw de aristotelische phronèsis: zorgvuldig omgaan met methodologische dilemma's}

In het recht worden sociale instituties niet alleen geëxpliciteerd, maar verkrijgen zij tevens een regelkarakter en worden zo tot afdwingbare handelingspatronen. Maar er is meer: juridische instituties worden als zodanig ook opgenomen in een specifiek wetenschappelijk kennissysteem, dat wij doorgaans aanduiden met termen als rechtsleer of rechtsdogmatiek. In die zin zijn juridische leerstukken op te vatten als vormen van geïnstitutionaliseerde juridische kennis en expertise. De neiging steekt dan vaak de kop op om die leerstukken te gaan verzelfstandigen en los te gaan beschouwen van de maatschappelijke of ethische werkelijkheid waarop zij een antwoord dienen te bieden. Zij verliezen dan elke referentie naar de buiten het recht gelegen maatschappelijke werkelijkheid en worden zelfreferentieel. Het dialectisch in evenwicht houden van een katascopische en een anascopische methode kan een belangrijk instrument vormen om een dergelijke zelfreferentialiteit te vermijden.

In de rechtswetenschap zijn - zeker op het Europese continent - vanuit de studie van het Romeins recht leerstukken uitgegroeid tot instituties waarin de normatieve patronen van het menselijke handelen worden uitgetekend en afdwingbaar worden gemaakt. Wanneer nu, zoals in Geigers diagnose van de hedendaagse sociologiebeoefening het geval is, ook in de rechtswetenschap én in de juridische vorming de katascopische benaderingswijze dominant tot zelfs exclusief wordt, leidt zulks tot een teloorgang van de machtskritische functie van het recht. Het recht wordt dan de spreekbuis van het staatsbelang dat daarmee de door de staat gewenste instituties en maatschappelijke waardepatronen zal weten te beschermen tegen innoverend en niet zelden afwijkend handelen van burgers. Homogenisering en centralisering van kennis en expertise gaan hand in hand met homogenisering en centralisering van de macht. ${ }^{13}$

Het is van het grootste belang voor een goede voorbereiding van de toekomstige juristen om hun rol in de uitbouw van een pluralistische samenleving op evenwichtige wijze te kunnen spelen dat zij niet worden opgeleid in een te dominante katascopische benadering, waarin de vanzelfsprekende wijze van denken die lijkt te zijn om uit het vaststaande leerstuk deductief de oplossing voor het concrete geval af te leiden. Een dergelijke aanpak zou een ernstige verenging van de juridische geest met zich meebrengen. In het kader van zijn bespreking van de hervorming van de rechtsstudies aan de universiteit van Bremen heeft de Duitse rechtsgeleerde Roland Dubischar hier krachtig op gewezen: 'Der (...) offizielle juristische Denk- und Begründungsstil diente dazu, Reflexionsverbote zu institutionalisieren, damit ein "staatstragendes" Vorverständnis gar nicht gefährdet werde' (Dubischar 1973, p. 91). Een eenzijdig katascopisch opgezet juridisch onderwijs-

13 De voormalige vicepresident van de Raad van State heeft hier herhaaldelijk op gewezen in de Algemene Beschouwingen bij de Jaarverslagen van de Raad. De dragende gedachte is dan steeds: 'geen samenspraak zonder tegenspraak' (Tjeenk Willink 2012). 
curriculum verhindert de vorming van toekomstige juristen als reflective practitioners.

Tegenover een katascopische benaderingswijze staat in Geigers analyse van het Doppelaspekt der Soziologie een anascopische banadering. Deze kenmerkt zich door een manier van denken van beneden naar boven. Vertrekpunt van denken zijn dan niet de instituties, maar het menselijk handelen, niet het leerstuk, maar de casus. Anders dan in het werk van Durkheim is in de verstehende Soziologie van Max Weber niet zozeer de sturende kracht van de sociale institutionaire structuur het vertrekpunt waarmee naar het handelen van mensen wordt gekeken: 'Object van Webers sociologie is het sociale zin-gerichte en zin-geladen handelen, ingebed in een zin-samenhang welke tijdens de handeling als motief werkzaam wordt' (Zijderveld 1974, p. 89). Weber, net als Durkheim jurist van vorming, trekt met zijn verstehende Soziologie een interessant spoor voor een praktijkgerichte rechtswetenschap. Weber was ervan overtuigd, en trok daar ook de methodologische consequenties uit, dat de sociale wetenschap, inclusief de rechtswetenschap, nooit abstractie mag maken van de subjectieve zin die mensen, partijen in een rechtsverhouding, in hun handelen tot uitdrukking en tot verwerkelijking trachten te brengen. Het is de taak van de praktijkgerichte wetenschapper om die subjectieve zin te erkennen en te begrijpen om zodoende de betekenis van het handelen op het spoor te kunnen komen. Natuurlijk spelen instituties, ook in de zin van juridische figuren, een belangrijke rol, maar zij kunnen nooit worden genomen als vanzelfsprekend vertrekpunt voor het verstaan van het handelen.

Een dergelijke meer anascopische benaderingswijze doet uiteraard meer recht aan het gezag van de feiten, aan de eigen waarde van de casus, die dan niet langer alleen maar voorwerp zou zijn van een vanzelfsprekende dogmatische kwalificatie, maar integendeel drager van een subjectieve zin die uitnodigt ook juridisch te worden verstaan. Een dergelijke anascopische benadering is meer aan de orde in een Angelsaksische rechtsopvatting dan in een Europees-continentale. Daarom is in een juridische opleiding een confrontatie van rechtsculturen van onmisbaar belang. Rechtsvergelijking is dan geboden als belangrijk onderdeel van het curriculum. Het dient daarbij niet zozeer te gaan om de algemene 'leerstellige' vergelijking van rechtsstelsels, zoals dat bijvoorbeeld in de klassieke rechtsvergelijking à la David het geval is (David 1964). In die benadering wordt de rechtsvergelijking nagenoeg uitsluitend bedreven vanuit een katascopische benadering. Een meer geëigende benadering van rechtsvergelijking dient te worden opgezet vanuit een vergelijkende studie van casuïstiek. Dat laatste is bijvoorbeeld het geval in de reeks handboeken die onder leiding van de Leuvense hoogleraar Walter van Gerven worden samengesteld: de Ius commune casebooks for the common law of Europe. ${ }^{14}$ Deze casebooks zijn uitdrukkelijk opgezet als een didactisch project voor de juridische opleiding. Het beoogt de toekomstige jurist gevoelig te maken voor het casuïstisch denken als toegang tot een passende rechtspraktijk in een pluralistische samenleving.

14 Zie over de hier gebruikte methode de inleiding tot het eerste casebook in de serie: Van Gerven 1998. 


\section{Case-based en case-oriented versus dogmatisch denken; inductief versus deductief redeneren}

Het is niet verwonderlijk dat een casuïstische, eerder anascopische benadering van rechtsbeoefening wordt uitgewerkt in de context van de Europese Unie, die zichzelf uitdrukkelijk niet presenteert als een nieuwe superstaat waarin een gecentraliseerde macht behoefte heeft aan het instrument van een gecentraliseerde en leerstellig gehomogeniseerde juridische kennis en expertise. Reeds in de Amerikaanse juridische opleiding, met name vanuit de vernieuwende inbreng van de Harvard Law School aan het eind van de negentiende eeuw, werd de case-based en de case-oriented method door haar founding fathers C.C. Langdell en anderen gezien als een opleidingsmethode die beter aansloot bij de politiek-maatschappelijke realiteit van een federale en in hoge mate gedecentraliseerde Verenigde Staten (Cavers 1961). Daarin is meer verscheidenheid - ook qua juridische regelgeving aan de orde dan in een sterk gecentraliseerde eenheidsstaat. Langdell en de zijnen verzetten zich tegen deze achtergrond sterk tegen het legal formalism met zijn eenzijdig katascopische doctrinaire karakter. Zij zagen er een ideologisch onderdrukken in van de werkelijke maatschappelijke dynamiek van de Amerikaanse samenleving en economie, bepaald als deze realiter werd door innoverend en grensverleggend handelen van burgers.

Natuurlijk was er een groot belang verbonden met het bekritiseerde formalisme. Met het dominant benadrukken van het 'wetenschappelijke' karakter van het recht als beschermingswal tegen het 'irrationele' karakter van de politiek kon rechtszekerheid en voorspelbaarheid worden gemaximaliseerd in een sterk door marktwerking gedomineerd bestel. De markt heeft immers alle belang bij een neutraliseren van de grillige onvoorspelbaarheid van de politiek, zo was de gedachte (Horwitz 1977). De prijs die hiervoor werd betaald dreigde gaandeweg te hoog te worden. Het juridisch formalisme leidde tot stagnatie en tot een rechtspraktijk die het innoverend burgerschap sterk frustreerde en miskende, en die alle reflectie op het eigen doen en laten was kwijtgeraakt. Het roer moest om, te beginnen bij de juridische opleiding: minder katascopie en meer anascopie in de gehanteerde methode.

Onze huidige Europese juridische faculteiten kunnen veel leren uit deze Amerikaanse methodenstrijd. Er moet worden vastgesteld dat de zich steeds nadrukkelijker ontwikkelende europeanisering van onze rechtsorde de vergelijking met de gedecentraliseerde Amerikaanse rechtsorde alleen maar dichterbij brengt. Het gaat in Europa om eenheid van recht in verscheidenheid van rechtsordes. Eenheid met erkenning van en respect voor verscheidenheid kan evenwel niet worden gerealiseerd vanuit een eenzijdig katascopisch denken. Een dergelijk project vraagt uitdrukkelijk om het ernstig nemen van de verscheidenheid die zich in de casuïstiek aandient en waarin via een comparatieve benadering onderlinge convergenties en divergenties dienen te worden opgespoord. Een dergelijke aanpak dient methodologisch van bij de aanvang van de opleiding te worden ingeoefend. 
Europeanisering en internationalisering van de juridische curricula is een absolute noodzaak geworden. Reeds ruim twee decennia geleden heeft de Amsterdamse comparatist De Boer daar in krachtige bewoordingen op gewezen:

'Wij moeten af van het provincialisme in de juridische opleiding waarin het recht van eigen bodem centraal staat en de aandacht van de studenten uitsluitend gericht wordt op de eigenaardigheden van het vaderlandse recht. Er zou veel meer tijd besteed moeten worden aan de gemeenschappelijke grondslagen van het recht in Europa, aan de overeenkomsten en verschillen tussen ons eigen recht en buitenlands recht en we zouden ons veel meer moeten openstellen voor andere juridische denkbeelden dan de onze. Anders gezegd: de rechtenstudie is toe aan internationalisering, aan internationale betrokkenheid, aan een universele visie op het recht.' (De Boer 1991, p. 33)

Laten we beginnen met Europa, want daar zijn krachtige redenen voor aan te geven.

\section{$9 \quad$ Europa als laboratorium voor juridische vorming}

Europa is het ideale laboratorium voor de aankomende jurist. Het verdient daarom sterk aanbeveling om de Europese dimensie vanaf het begin van de studie uitdrukkelijk aan de orde te stellen. Op die wijze kan kennis worden gemaakt met het ontstaan en de groei van een rechtsorde vanuit een pluraliteit van visies en uitgangspunten. Natuurlijk is het belangrijk dat niet alleen afzonderlijke vakken Europees recht, zowel institutioneel als materieel, in de latere fasen van de studie worden aangeboden. Maar ook hier moet worden gewaarschuwd tegen een te eenzijdige katascopische benadering. Specifieke vakken Europees recht winnen alleen maar aan belang wanneer zij, van bij de aanvang van de studie, bij voorkeur reeds in de inleiding tot de rechtswetenschap in het eerste jaar, worden voorbereid doordat studenten gevoelig worden gemaakt voor vergelijking van rechtsculturen in Europa op het niveau van de concrete casuïstiek.

Die vergelijking kan de student doen kennismaken met de fascinerende vaststelling die de genese van het Europees recht sinds het Verdrag van Rome te zien geeft. Om met de al eerder geciteerde formulering van Harold Berman te spreken: ook het Europees recht tells a story. Dat verhaal is er een van de confrontatie van rechtsopvattingen met elk hun theoretische traditie, zowel in de prefilosofische als in de filosofische betekenis van theorie. De Franse juridische traditie, gegroeid uit de napoleontische codificatie, maar ook doortrokken van het cartesiaanse kennisideaal van logiciteit en more geometrico-denken, is sterk conceptueel en formalistisch. De dominante methodologie is katascopisch: van het leerstuk naar de casus via de weg der deductie. De Duitse juridische traditie, sterk beïnvloed door het natuurrecht, door het daarmee samenhangende verzet tegen het juridisch positivisme (vooral na de Tweede Wereldoorlog) en door de wijsgerige traditie van het Duitse idealisme, is veel sterker gefocust op substantiële waarden, op morali- 
teit en zedelijkheid. Om met de woorden van de filosoof Hegel te spreken: het recht institutionaliseert de zich in de geschiedenis ontvouwende Sittlichkeit van de samenleving. Niet zozeer logiciteit en conceptuele systematiciteit staan hierbij op het voorplan, maar zedelijkheid. Ook hier is de dominante aanpak katascopisch. De soevereine lidstaat Duitsland acht zich de uiteindelijke hoeder van deze in juridische instituties uitgekristalliseerde zedelijkheid. Vandaar het primaat van de Duitse federale rechter, niet alleen op de rechtspraak van de Länder, maar ook op de Europese rechter.

Die controverse maakt deel uit van het verhaal van het Europees recht. Met de toetreding van het Verenigd Koninkrijk tot de Europese Gemeenschap is er evenwel nog een derde juridische traditie tot de Europese juridische ruimte toegetreden. Anders dan de Franse en de Duitse, hoe verscheiden die onderling reeds zijn, is de Angelsaksische traditie veeleer pragmatisch te noemen. Dat hangt uiteraard samen met de common law-traditie, die voortbouwt op een andere receptie van het Romeins recht dan de continentale rechtsordes van Frankrijk en Duitsland. Niet de in het elfde en twaalfde-eeuwse Bologna verwetenschappelijkte studie van de justiniaanse codificatie domineert het juridische netvlies van de Angelsaksische jurist, maar veeleer de pre-justiniaanse rechtspraktijk van de res cotidiana en de strategie van flexibele conflictbeslechting die daarmee samenhangt. Zij kleuren het zelfbeeld en vooral de professional self-consciousness van de Angelsaksische jurist. De wijsgerige traditie van het typisch Angelsaksische empirisme à la Hume en anderen versterkt dit juridische pragmatisme. Hier is de methodologische aanpak sterk anascopisch. Het dominante theoriebegrip in het Angelsaksische recht is sterk narratief en sluit dus direct aan bij wat wij in deze bijdrage een prefilosofische opvatting van theorie hebben genoemd. Sterk gericht op waarneming van de feiten en veel minder op conceptueel denken. Dat is ook de reden waarom de Oxford-civilist Patrick Atiyah in zijn beroemde Hamlyn Lectures als een van de belangrijkste kenmerken van het Angelsaksische rechtsdenken noemt dat de theorie er - omwille van praktische flexibiliteit - 'remains beneath the surface' (Atiyah 1987, p. 143-184).

Het verhaal van het Europese recht houdt een fascinerende zoektocht in naar de wijze waarop drie zulke uiteenlopende rechtsculturen - de Franse, de Duitse en de Angelsaksische - in één rechtsorde met elkaar kunnen worden geïntegreerd. Onze rechtenstudenten moeten zich in dit verhaal kunnen begeven en het van binnenuit meebeleven. Dat is van belang omdat hier een waar laboratorium voor rechtsontwikkeling en rechtsvorming wordt geboden, waarin alle dilemma's en spanningen van het hedendaagse recht ook in methodologische zin fungeren. De spanning tussen twee opvattingen van theorie en van de rol die theorie heeft te spelen. Maar ook de spanning tussen een eerder katascopische benadering enerzijds en een eerder anascopische benadering anderzijds. Ten slotte ook de spanning in de driehoek die kan worden opgespannen tussen de op logica en conceptuele consistentie drijvende rechtszekerheid, de op gemeenschappelijke en sterk geïnstitutionaliseerde zedelijkheid steunende rechtvaardigheid en vervolgens de 
doeltreffendheid en de doelmatigheid zo eigen aan de pragmatiek van de juridische conflictbeslechting. ${ }^{15}$

Het laboratorium dat de Europese rechtsontwikkeling ons didactisch aanreikt geeft een bijzondere dimensie aan al deze spanningsverhoudingen. Immers: de drie grote rechtsculturen - de Franse, Duitse en Angelsaksische - zijn in louter theoretisch opzicht (in de zin van wetenschappelijke theorie) incompatibel met elkaar en haast onmogelijk met elkaar te harmoniseren. ${ }^{16}$ Niettemin dient te worden vastgesteld dat er - ondanks de enorme theoretische divergenties - in de praktijk van de besluitvorming door het Europese Hof van Justitie sterke mechanismen van onderlinge convergentie tot ontwikkeling worden gebracht. Er is sprake van wat de voormalige advocaat-generaal bij het Hof Walter van Gerven heeft gekarakteriseerd als een voortgaand proces van 'bridging the unbridgeable' (Van Gerven 1996).

Het in de praktijk in gang zetten van mechanismen van convergentie tussen de uiteenlopende nationale rechtsculturen is mogelijk geworden doordat het Hof zijn methode van redeneren en vervolgens van motiveren sinds de casuïstiek van Francovich en Brasserie du Pêcheur grondig heeft gewijzigd. De redeneerwijze van het Hof is sindsdien veel meer in termen van algemene rechtsbeginselen dan van regelgeving uit de verdragen. Daardoor kan een dynamisch proces in gang worden gezet - en ook door het Hof enigszins gestuurd - van een interpretatiepraktijk met betrekking tot algemene rechtsbeginselen die niet alleen typisch zijn voor de Europese rechtsorde, maar tevens voor de onderscheiden nationale rechtsordes van de lidstaten. Er ontstaat zodoende een gezamenlijke en gedeelde interpretatiepraktijk van ook gemeenschappelijk gedragen rechtsbeginselen, over de grenzen heen van zeer uiteenlopende wetenschappelijk-theoretische achtergronden.

\section{Beginselenonderwijs}

Het Europees recht als didactisch laboratorium voor het juridisch onderwijs geeft zodoende ook de richting aan voor wat beginselenonderwijs genoemd kan worden. ${ }^{17}$ Het gaat dan over het aanleren van wat Paul Scholten al in het begin van de twintigste eeuw grondgedachten heeft genoemd, die in een uiteenlopende variëteit van regelgeving en rechterlijke uitspraken aan het werk zijn en aan die variëteit een zekere gezamenlijke waardeoriëntatie verlenen. Rechtsbeginselen zijn geen normen van natuurrecht, noch vaststaande grondslag waaruit regels en oordelen deductief zouden kunnen worden afgeleid. Scholten gaat op zoek naar samenhang, naar een normatieve coherentie in de diversiteit van singuliere

15 Gustav Radbruch sprak in zijn rechtsfilosofie - lang vóór het ontstaan van de Europese Gemeenschap - al over deze driehoek als 'die Antinomien der Rechtsidee', daarmee aangevend dat de drie polen van deze driehoek geen natuurlijk onderling evenwicht kennen, maar 'zueinander in schärfen Widerspruch treten können' (Radbruch 1963, p. 173).

16 Deze problematiek van theoretische incompatibiliteit werd uitvoerig geanalyseerd in Foqué \& Steenbergen 2009.

17 Zie voor een kritische analyse van het beginselendenken Foqué 2010. 
regelgeving en oordeelsvorming. Enige decennia later zal de Amerikaanse rechtsgeleerde Ronald Dworkin een dergelijk project aanduiden als een zoeken naar 'integrity in law' (Dworkin 1986, p. 225 e.v.). Scholtens redeneerwijze vertrekt in een anascopische beschouwing bij de praktijk van regelgeving en rechtspraak, maar gaat tegelijk op zoek naar de waardeoriëntaties die achter en in die praktijk worden aangesproken, en waarvan die praktijk niet los gezien kan worden:

'In en achter ieder in wetsvoorschriften en rechterlijke uitspraken belichaamd rechtssysteem liggen grondgedachten waarvan de bijzondere bepalingen en beslissingen als uitwerkingen kunnen worden gedacht. Die gedachten zijn evenzeer deel van het recht als die voorschriften en uitspraken zelf.' (Scholten 1949 , p. 402)

In deze passage zijn reeds een aantal fundamentele rechtstheoretische inzichten aan de orde met grote politieke en praktische relevantie. Het belangrijkste daarvan is zonder twijfel dat de achterliggende grondgedachten, de referenties naar algemenere waardeoriëntaties, niet in een instrumentalistische sleutel worden gezet. $\mathrm{Zij}$ worden integendeel van meet af aan niet als buiten het recht tot stand gekomen opties gethematiseerd, in de realisering waarvan het positieve recht dan als instrument zou kunnen worden ingezet, maar als 'evenzeer deel van het recht' (Scholten 1949, p. 396).

'Het rechtsbeginsel vraagt om formuleering (...) alleen als formule is het in rechte te hanteeren', aldus Scholten, en hij voegt eraan toe:

'Dikwijls, het is niet tegen te spreken, is het moeilijk intellectueel werk in verspreid liggende bepalingen het gemeenschappelijke te vinden. Het blootleggen der fundamenten eischt inzicht en inspanning. Doch àls zij eenmaal aangewezen zijn, zijn ze voor ieder zichtbaar, evident, is tevens aangetoond, dat zij er al waren toen de eerste bepaling, waarin zij worden teruggevonden in het leven werd geroepen.' (Scholten 1949, p. 402-403)

Het opsporen en zichtbaar maken van rechtsbeginselen en hen tot inzet maken van een interpretatieve arbeid dient een van de hoekstenen te zijn van een methodologie van juridisch onderwijs. En nogmaals: het Europees recht biedt een uitstekend heuristisch laboratorium aan om de aankomende jurist hiermee vertrouwd te maken.

Beginselenonderwijs introduceert inderdaad een nieuw didactisch project in de opleiding. Regelgeving en precedentenrecht worden daarin niet gedecontextualiseerd aangeleerd en gememoriseerd, maar zij worden integendeel ingebed en begrepen vanuit de impliciete beginselen die hen normatieve kracht en samenhang verlenen. Systematiek en institutionalisering zijn hier een karakteristiek van het recht die niet losstaat van casuïstische dynamiek en vernieuwing. Maar ook omgekeerd: tirannie van de casuïstiek kan worden vermeden door de systematiek te articuleren van de onderliggende beginselen als een implicit philosophy. 
In de woorden van Ronald Dworkin ligt ook de grondslag besloten voor het didactische project van beginselenonderwijs:

'Members of a society of principle accept that their political rights and duties are not exhausted by the particular decisions their political institutions have reached, but depend, more generally, on the scheme of principles those decisions presuppose and endorse.' (Dworkin 1986, p. 211)

Samengevat: in beginselenonderwijs worden de twee eerdergenoemde opvattingen van theorie dialectisch op elkaar betrokken, alsook de beide polen van wat Theodor Geiger het Doppelaspekt der sociale wetenschap noemde: het methodologische dilemma van katascopie en anascopie. Zodoende kan het evenwicht in de driehoek rechtszekerheid, rechtvaardigheid en doelmatigheid worden gerealiseerd als een steeds opnieuw te ontdekken reflective equilibrium, niet dogmatisch versteend, maar casuïstisch aan het werk onder de medeverantwoordelijkheid en de regie van goed opgeleide professionals als reflective practitioners.

\section{Literatuur}

\section{Arendt 1958}

H. Arendt, The Human Condition, Chicago/London: The University of Chicago Press 1958.

\section{Atiyah 1987}

P.S. Atiyah, Pragmatism and Theory in English Law, London: Stevens 1987.

\section{Berman 1983}

H.J. Berman, Law and Revolution. The Formation of the Western Legal Tradition, Cambridge (Mass.)/London: Harvard University Press 1983.

\section{De Boer 1991}

Th.M. de Boer, 'Universalisme en provincialisme in de rechtenstudie: de noodzaak van internationalisering', in: J.B.M. Vranken e.a. (red.), In het nu wat worden zal. Opstellen aangeboden aan Prof. Mr. H.C.F. Schoordijk ter gelegenheid van zijn afscheid als hoogleraar aan de Katholieke Universiteit Brabant, Deventer: Kluwer 1991, p. 29-37.

\section{Cavers 1961}

D.F. Cavers, 'Legal Education in the United States', in: H.J. Berman (ed.), Talks on American Law. A Series of Broadcasts to Foreign Audiences by Members of the Harvard Law

\section{David 1964}

School Faculty, New York: Vintage Books 1961, p. 193-207.

R. David, Les grands systèmes de droit contemporains (droit comparé), Paris: Dalloz 1964.

Dubischar 1973

R. Dubischar, 'Juristisches Denken als Objekt juristischer Selbstreflexion und sozialwissenschaftlicher Forschung', in: A. Rinken e.a., Der neue Jurist. Materialien zur reformierten Juristenausbildung in Bremen, Neuwied/Darmstadt: Luchterhand 1973, p. 89-106.

\section{Dworkin 1986}

R. Dworkin, Law's Empire, Cambridge (Mass.)/London: Harvard University Press 1986. 


\section{Eggens 1958}

J. Eggens, 'Over het fingeren van rechtsficties' (oratie Universiteit van Amsterdam, 1958), in: J. Eggens, Verzamelde privaatrechtelijke opstellen, deel 2, Alphen aan den Rijn: Samsom 1959, p. 314-328.

\section{Fink 1976}

E. Fink, 'Phronèsis und Theoria', in: W. Biemel (Hrsg.), Die Welt des Menschen - Die Welt der Philosophie. Festschrift für Jan Patocka, Den Haag: Martinus Nijhoff 1976, p. 134-158.

\section{Foqué 1995}

R. Foqué, 'Het recht van de verscheidenheid', in: Chr. de Vries \& K. Schuyt (red.), De open samenleving en haar vrienden. In gesprek met Jan Glastra van Loon, Amsterdam/ Meppel: Boom 1995, p. 145-169.

\section{Foqué 1997}

R. Foqué, 'De dialectiek van rechtsvorming en juristenvorming', in: J. ten Kate e.a. (red.), Miscellanea Jurisconsulto vero Dedicata, Deventer: Kluwer 1997, p. 41-63.

\section{Foqué 2001}

R. Foqué, 'Samenhang en tegenhang in twee decennia strafrechtstheorie', Panopticon 2001-2, p. 123-140.

\section{Foqué 2004}

R. Foqué, 'Iuris prudentia', in: K. Geens e.a. (red.), Ad amicissimum amici scripsimus. Vriendenboek Raf Verstegen, Brugge: Die Keure 2004, p. 112-116.

\section{Foqué 2010}

R. Foqué, 'De crisis van het juridisch fundamentalisme. Instrumentaliteit en rechtsbescherming in het licht van Scholtens beschouwingen', in: A. Ellian e.a. (red.), Recht, beslissing en geweten. Beschouwingen naar aanleiding van Paul Scholten, Deventer: Kluwer 2010, p. 223-241.

\section{Foqué \& 't Hart 1990}

R. Foqué \& A.C. 't Hart, Instrumentaliteit en rechtsbescherming, Arnhem/Antwerpen: Gouda Quint/Kluwer 1990.

\section{Foqué \& Steenbergen 2009}

R. Foque \& J. Steenbergen, 'The Limits of the Law and the Development of the EU', in: E. Claes e.a. (eds.), Facing the Limits of the Law, Berlin/Heidelberg: Springer Verlag 2009, p. 205-236.

\section{Gatti-Montain 1987}

J. Gatti-Montain, Le système d'enseignement du droit en France, Lyon: Presses Universitaires de Lyon 1987.

\section{Geiger 1962}

Th. Geiger, Arbeiten zur Soziologie. Methode, Moderne Grossgesellschaft, Rechtssoziologie, Ideologiekritik, Neuwied/Berlin: Luchterhand 1962.

\section{Van Gerven 1996}

W. van Gerven, 'Bridging the Unbridgeable. Community and National Tort Laws after Francovich and Brasserie', The International and Comparative Quarterly 1996, p. 507-544.

\section{Van Gerven 1998}

W. van Gerven, Tort Law. Scope of Protection, Oxford: Hart Publishing 1998.

\section{Ter Heide 1967}

J. ter Heide, 'Iudex viator. Probleem- of systeemdenken, of gesystematiseerd probleemdenken', Ars Aequi 1967-1, p. 3-31. 


\section{Horwitz 1977}

M.J. Horwitz, 'The Rise of Legal Formalism', in: M.J. Horwitz, The Transformation of American Law 1780-1860, Cambridge (Mass.)/London: Harvard University Press 1977, p. 253-266.

\section{Larenz 1960}

K. Larenz, Methodenlehre der Rechtswissenschaft, Berlin/Heidelberg: Springer Verlag 1960.

\section{Plessner 1948}

H. Plessner, 'Zur Anthropologie des Schauspielers', in: H. Plessner, Zwischen Philosophie und Gesellschaft. Ausgewählte Abhandlungen und Vorträge, Bern: Francke Verlag 1953, p. 180-192.

\section{Radbruch 1963}

\section{Rausch 1982}

G. Radbruch, Rechtsphilosophie (6. Auflage), Stuttgart: Koehler Verlag 1963.

H. Rausch, Theoria. Von Ihrer sakralen zur philosophischen Bedeutung, München: Wilhelm Fink Verlag 1982.

\section{Schapp 1953}

W. Schapp, In Geschichten Verstrickt. Zum Sein von Mensch und Ding, Frankfurt am Main: Klostermann 1953 (3e druk 1985).

\section{Scholten 1949}

P. Scholten, 'Rechtsbeginselen', in: P. Scholten, Verzamelde geschriften, deel 1, Zwolle: Tjeenk Willink 1949, p. 395-412.

\section{Schön 1983}

D.A. Schön, The Reflective Practitioner. How Professionals Think in Action, New York: Basic Books 1983.

\section{Steel 1989}

C. Steel, 'Verstandigheid en moraliteit', in: H. Parret (red.), In alle redelijkheid. Standpunten over het denken, spreken en handelen van de redelijke mens, Meppel/Amsterdam: Boom 1989, p. 101-115.

\section{Tjeenk Willink 2012}

H.D. Tjeenk Willink, 'Een gematigde staatsvorm en een fatsoenlijke samenleving', in: M.C. Foblets e.a. (red.), Liber Amicorum René Foqué, Brussel/Den Haag: Larcier/Boom Juridische uitgevers 2012, p. 103-114.

\section{Wassermann 1979}

R. Wassermann, 'Vorwort', in: H.E. Troje, Juristenausbildung heute. Eine rechts- und sozialwissenschaftliche Studie, Neuwied/Darmstadt: Luchterhand 1979, p. 8.

\section{Wilhelm 1958}

W. Wilhelm, Zur juristischen Methodenlehre im 19. Jahrhundert. Die Herkunft der Methode Paul Labands aus der Privatrechtswissenschaft, Frankfurt am Main: Klostermann 1958.

\section{Zijderveld 1974}

A.C. Zijderveld, Institutionalisering. Een studie over het methodologisch dilemma der sociale wetenschappen, Meppel: Boom 1974, i.h.b. p. 11-27. 